\title{
Faktor-Faktor Penyebab Terjadinya Temuan Berulang Atas Pemeriksaan Oleh Inspektorat Kota Gorontalo
}

\author{
INDRAWATI NUNU ${ }^{1}$, JULLIE J. SONDAKH ${ }^{2}$, WINSTON PONTOH ${ }^{3}$ \\ Program Magister Akuntansi, Fakultas Ekonomi dan Bisnis Universitas Sam Ratulangi \\ email: azza indah14@ymail.com
}

\begin{abstract}
This study aims to determine the factors that cause the occurrence of recurring findings on the Inspectorate check and to analyze the coaching role of the Inspectorate in order to minimize the recurring findings. The recurring findings are the findings with same problems, which are repetitive from year to year although the previous findings have been resolved. The recurring findings are not only in the form of the loss of the local government, but also in terms of the administrative arrangement including the aspects of financial management, personnel management, the implementation of the basic tasks and functions, and the management of local government asset. The priciple theory used for this study includes the agency theory, positive accounting theory, compliance theory, attribution theory, and the theory of organizational commitment. This research employs a qualitative method and an exploratory approach. This approach elaborates more about the research topic based on the information collected from the interviews with the participants. These data were triangulated with other data obtained from observation and document analysis and then, they were analyzed interactively by reducing, presenting in the form of texts and tables, and making a conclusion. The result shows that the factors that cause recurring findings on the examination of the Inspectorate from the auditors' side are: 1) lack of coordination and communication in the audits; 2) lack of auditor competence in developing the findings. On the contrary, from the side of the auditee, the factors are: 1) the lack of coordination and communication in the audits; 2) lack of integrity and ethical values; 3) weak internal control systems; 4) lack of management commitment; 5) mutation of the financial managers; and 6) regulatory changes. Inspectorate has made various efforts to minimize their recurring findings in the form of guidance to the Local Government Unit, but in fact it can be said not effective. Suggestion that can be given to the auditor/head of the Inspectorate is to improve the communication and coordination with the object of examination and other related SKPD as well as to enhance the competence, especially in developing the audit findings. In addition, the leaders of SKPD (auditee) should be more active in making further coordination with the inspectorate, controlling the application of SPIP and creating the Standard Operating Procedure (SOP) for each activity.
\end{abstract}

Keywords: Recurring findings, Guidance, Inspectorate.

Abstrak. Penelitian ini bertujuan untuk mengetahui faktor-faktor penyebab terjadinya temuan berulang atas pemeriksaan Inspektorat serta menganalisis peran pembinaan Inspektorat dalam upaya meminimalisir adanya temuan berulang. Temuan berulang adalah temuan dengan permasalahan yang sama, yang selalu berulang dari tahun ke tahun walaupun temuan sebelumnya telah ditindaklanjuti. Temuan berulang yang dimaksud tidak hanya dalam bentuk kerugian daerah namun juga dari sisi penataan administrasi baik dari aspek pengelolaan keuangan, pengelolaan aparatur, pelaksanaan tugas pokok dan fungsi, dan pengelolaan aset daerah. Teori dasar yang digunakan dalam penelitian ini meliputi teori keagenan, teori akuntansi positif, teori kepatuhan, teori atribusi, dan teori komitmen organisasi. Penelitian ini merupakan jenis penelitian metode kualitatif dengan pendekatan eksploratori. Pendekatan ini bertujuan untuk mencari tahu lebih dalam mengenai topik penelitian berdasarkan informasi yang dikumpulkan dari narasumber melalui wawancara. Data ini ditriangulasikan dengan data lain yang diperoleh dari observasi dan studi dokumentasi, kemudian dianalisis secara interaktif dengan mereduksi, menyajikan dalam bentuk teks dan tabel, dan membuat suatu kesimpulan. Hasil penelitian ini menunjukkan bahwa faktor-faktor 
yang menyebabkan terjadinya temuan berulang atas pemeriksaan Inspektorat dari sisi auditor adalah: 1) kurangnya koordinasi dan komunikasi audit; 2) kurangnya kompetensi auditor dalam pengembangan temuan. Sedangkan dari sisi auditi adalah: 1) kurangnya koordinasi dan komunikasi audit; 2) kurangnya integritas dan nilai etika; 3) lemahnya sistem pengendalian intern; 4) tidak adanya komitmen pimpinan; 5) adanya mutasi pengelola keuangan; dan 6) perubahan regulasi. Inspektorat telah melakukan berbagai upaya dalam meminimalisir adanya temuan berulang dalam bentuk pembinaan kepada Satuan Kerja Pemerintah Daerah (SKPD), namun pada kenyataannya dapat dikatakan belum efektif. Saran yang dapat diberikan bagi auditor/pimpinan Inspektorat adalah memperbaiki komunikasi dan koordinasi dengan objek pemeriksaan dan SKPD terkait lainnya serta lebih meningkatkan kompetensinya terutama dalam hal pengembangan temuan audit. Sedangkan untuk pimpinan SKPD (auditi) diantaranya lebih aktif dalam melakukan koordinasi lebih lanjut dengan Inspektorat, melakukan pengendalian dalam bentuk penerapan SPIP dan membuat Standar Operasional Prosedur (SOP) untuk setiap kegiatan.

Kata Kunci : Temuan berulang, Pembinaan, Inspektorat.

\section{Pendahuluan}

Dalam rangka mewujudkan tata kelola pemerintahan yang baik (good governance), diperlukan peran pengawasan internal pemerintah secara optimal dan berkualitas. Pengawasan yang merupakan unsur penting dalam proses manajemen pemerintahan, memiliki peran yang sangat strategis untuk terwujudnya akuntabilitas publik dalam pemerintahan dan pembangunan. Pengawasan terhadap urusan pemerintahan di daerah dilaksanakan oleh Aparat Pengawas Intern Pemerintah (APIP) sesuai dengan fungsi dan kewenangannya, dalam hal ini dilakukan oleh Inspektorat Daerah.

Sesuai PP No. 60 Tahun 2008 tentang SPIP Pasal 49 ayat (6) dinyatakan bahwa Inspektorat Kabupaten/Kota melakukan pengawasan terhadap seluruh kegiatan dalam rangka penyelenggaraan tugas dan fungsi satuan kerja perangkat daerah kabupaten/kota yang didanai dengan Anggaran Pendapatan dan Belanja Daerah Kabupaten/Kota. Inspektorat Daerah Provinsi dan Kabupaten/Kota dalam melaksanakan kegiatan pengawasannya, mengacu pada Permendagri Nomor 23 Tahun 2007 tentang Pedoman Tata Cara Pengawasan atas Penyelenggaraan Pemerintahan Daerah dan Permenpan \& RB Nomor 5 Tahun 2008 tentang Standar Audit Aparat Pengawasan Internal Pemerintah (SAAPIP).

Dalam melaksanakan pengawasan internal, Inspektorat Kota Gorontalo tidak hanya terbatas pada kegiatan pengawasan/audit tapi juga melaksanakan fungsi pembinaan terhadap satuan kerja pemerintah daerah (SKPD). Kegiatan pengawasan yang dilakukan diantaranya pengawasan internal secara berkala (audit reguler), penanganan kasus pengaduan di lingkungan Pemerintah Daerah (audit dengan tujuan tertentu), reviu Laporan Keuangan Pemerintah Daerah, evaluasi Akuntabilitas Kinerja Instansi Pemerintah (AKIP), monitoring tindak lanjut hasil pemeriksaan, serta kegiatan pengawasan lainnya. Sedangkan kegiatan pembinaan yang dilakukan Inspektorat Kota Gorontalo dalam upaya mencegah dan meminimalisir terjadinya berbagai penyimpangan berupa salah saji maupun kecurangan, agar tidak terjadi lagi di masa mendatang yaitu kegiatan verifikasi Jumat Bersih Administrasi yang dilaksanakan setiap minggu, pembinaan pada saat penugasan pemeriksaan reguler, pembinaan secara langsung dengan mendatangi auditi, serta pembinaan yang bersifat non formal lainnya.

Paradigma Inspektorat saat ini telah berubah dari yang tadinya sebagai pemeriksa, namun saat ini lebih ditekankan pada kegiatan pembinaan kepada seluruh satuan kerja di lingkungan Pemerintah Kota Gorontalo. Hal tersebut sangat perlu dilakukan guna 
mewujudkan tata kelola pemerintahan yang baik dan bersih dari praktik-praktik Korupsi, Kolusi dan Nepotisme (KKN). Namun walaupun telah dilakukan berbagai pembinaan secara terusmenerus dan perubahan pola pikir APIP sebagai pemberi peringatan dini (early warning) terhadap temuan pelanggaran atau penyimpangan yang berindikasi KKN, fenomena yang terjadi saat ini masih ditemukan beberapa temuan hasil pemeriksaan Inspektorat Kota Gorontalo yang memiliki kesamaan dengan temuan pada tahun-tahun sebelumnya.

Selain itu, dalam meningkatkan sistem pengawasan internal Inspektorat juga melakukan kegiatan evaluasi penyelesaian tindak lanjut hasil pemeriksaan yang dilakukan dengan pola pemantauan kepada satuan kerja yang belum melaksanakan tindak lanjut. Salah satu tujuan dari kegiatan tindak lanjut hasil pemeriksaan adalah memastikan bahwa temuan yang diperoleh dalam audit sebelumnya tidak dijumpai lagi dalam audit yang sedang dilaksanakan (Astriani, 2013). Namun pada kenyataannya berdasarkan data tindak lanjut hasil pemeriksaan Inspektorat Kota Gorontalo, masih ditemukan beberapa temuan audit sebelumnya yang masih dijumpai lagi pada audit berikutnya. Dengan demikian dapat dikatakan bahwa tujuan untuk mencegah dan menghindari kesalahan yang serupa melalui kegiatan pembinaan dan evaluasi penyelesaian tindak lanjut hasil pemeriksaan, tidak dapat terlaksana dengan baik.

Penelitian Kusuma (2014) mengungkapkan bahwa faktor penyebab tidak efektifnya penanganan temuan berulang pemeriksaan Inspektorat antara lain: 1) koordinasi antara auditor Inspektorat dengan objek pemeriksaan dan SKPD lain tidak berjalan dengan baik dan berkelanjutan serta saling melemparkan tanggung jawab koordinasi; 2) tidak ada standar operasional model pemeriksaan; 3) pemahaman yang kurang tepat atas posisi Inspektorat dimata auditor; 4) tidak adanya sanksi yang tegas kepada objek pemeriksaan yang memiliki temuan berulang. Demikian halnya dengan Isminarsih (2015) dalam penelitiannya menyimpulkan bahwa temuan berulang di SKPD disebabkan oleh : 1) tidak adanya ketegasan dari pihak Inspektorat yang tidak bisa memberikan sanksi yang cukup berat kepada objek pemeriksaan; 2) pimpinan/pejabat yang menangani kegiatan tidak memperhatikan ketentuan dan peraturan yang berlaku; 3) kurangnya komunikasi dan koordinasi antara auditor dan objek pemeriksaan. Dengan demikian, dapat diartikan bahwa penyebab terjadinya temuan berulang bukan hanya terdapat pada sisi SKPD sebagai objek pemeriksaan, namun juga terdapat pada auditor Inspektorat itu sendiri sebagai pengawas internal.

Tujuan yang ingin dicapai dalam penelitian ini adalah untuk mengetahui faktor-faktor yang menyebabkan terjadinya temuan berulang atas pemeriksaan Inspektorat Kota Gorontalo dan menganalisis peran Inspektorat terhadap pembinaan pada SKPD sebagai objek pemeriksaan dalam meminimalisir adanya temuan berulang.

\section{Model Analisis}

Model/kerangka analisis penelitian ini dimulai dari menentukan topik penelitian yaitu temuan audit berulang yang diperoleh dari tahapan-tahapan dalam penugasan audit Inspektorat. Langkah berikutnya, menentukan fokus penelitian yaitu faktorfaktor penyebab temuan berulang dilihat dari sisi Inspektorat sebagai aparat pengawas dan dari sisi objek pemeriksaan, selanjutnya menganalisis peran Inspektorat dalam memberikan pembinaan kepada objek pemeriksaan. 


\section{Metode Penelitian}

Penelitian ini menggunakan metode penelitian kualitatif dengan pendekatan eksploratori (exploratory approach). Metode ini digunakan agar data yang diperoleh akan lebih lengkap, lebih mendalam, kredibel dan bermakna sehingga tujuan penelitian dapat tercapai. Penelitian eksploratori merupakan suatu pendekatan penelitian yang digunakan untuk meneliti sesuatu (yang menarik perhatian) yang belum diketahui, belum dipahami, belum dikenali, dengan baik (Amirin, 2009). Teknik pengumpulan data yang digunakan dalam penelitian ini adalah melalui wawancara mendalam (indepth interview), observasi (observation), dan studi dokumentasi (documentation). Selanjutnya, uji validitas data dalam penelitian ini meliputi uji credibility (kepercayaan) yang dilakukan dengan menggunakan metode triangulasi sumber dan triangulasi teknik, dan uji dependability/reliabilitas (kebergantungan).

Metode analisis data yang dgunakan adalah interactive analysis (analisis interaktif). Aktivitas analisis data yang dikemukakan oleh Miles and Huberman dalam Sugiyono (2015) terdiri atas: data reduction, data display dan conclusion drawing/verification yang dilakukan secara terus menerus sampai tuntas, sehingga datanya mencapai jenuh.

\section{Hasil Penelitian dan Pembahasan}

Berdasarkan hasil penelitian yang diperoleh dari teknik wawancara, observasi dan studi dokumentasi, selanjutnya dilakukan interpretasi atas hal-hal yang ditemukan sesuai dengan teori yang mendukung hasil penelitian.

\section{Tahap Penugasan Audit}

Berdasarkan Lampiran II Permendagri Nomor 23 Tahun 2007 tentang Pedoman Tata Cara Pengawasan Atas Penyelenggaraan Pemerintahan Daerah, mekanisme dalam melakukan audit terdiri dari persiapan audit (perencanaan), pelaksanaan audit dan pelaporan audit. Demikian halnya pada Inspektorat Kota Gorontalo, tahapan penugasan audit dimulai dari perencanaan audit, pelaksanaan audit, pelaporan hasil audit, dan penyelesaian tindak lanjut hasil audit.

\section{Temuan Audit Berulang}

Menurut Rai (2008) temuan audit adalah masalah-masalah (material) yang ditemukan selama audit berlangsung dan masalah tersebut pantas untuk dikemukakan dan dikomunikasikan dengan entitas yang diaudit karena mempunyai dampak terhadap perbaikan dan peningkatan kinerja (ekonomi, efisiensi dan efektivitas) entitas yang diaudit. Temuan audit berasal dari perbandingan kondisi (apa yang sebenarnya terjadi) dengan kriteria (apa yang seharusnya terjadi), mengungkap akibat yang ditimbulkan dari perbedaan kondisi dan kriteria tersebut serta mencari penyebabnya.

Temuan berulang adalah temuan dengan permasalahan yang sama, yang selalu berulang dari tahun ke tahun walaupun temuan sebelumnya telah ditindaklanjuti. Menurut Cahill (2012), temuan berulang dapat didefinisikan sebagai:

1) A finding that was identified in the previous independent audit for which a corrective action has not been completed as planned;

2) A finding that is substantially similar in nature to one that was identified in the previous independent audit. 
Jika dihubungkan dengan teori keagenan (agency theory), Pemerintah Daerah dalam hal ini Satuan Kerja Perangkat Daerah (SKPD) bertindak sebagai agen untuk melaksanakan tugas pemerintahan yang diberikan oleh masyarakat sebagai prinsipal. Pemerintah sebagai pengguna anggaran publik harus mengelola dan mempertanggungjawabkan anggaran dan keuangan negara/daerah kepada masyarakat, sesuai dengan ketentuan dan peraturan perundang-undangan. Namun, pada kenyataannya terdapat individuindividu dalam Satuan Kerja Perangkat Daerah (SKPD) yang ingin memiliki keuntungan dengan mendahulukan kepentingan pribadi/kelompok dan mengabaikan kepentingan organisasi. Dengan demikian, aparatur pemerintah daerah akan bertindak tidak sesuai dengan keinginan masyarakat yang ditandai dengan perilaku yang tidak etis dan cenderung melakukan penyimpangan.

\section{Faktor-Faktor Penyebab Temuan Berulang}

Berdasarkan hasil penelitian yang telah dilakukan, diketahui faktor-faktor yang menyebabkan terjadinya temuan berulang atas pemeriksaan Inspektorat Kota Gorontalo adalah: 1) kurangnya koordinasi dan komunikasi audit; 2) kurangnya kompetensi auditor dalam pengembangan temuan; 3) kurangnya integritas dan nilai etika aparatur; 4) lemahnya sistem pengendalian intern; 5) kurangnya komitmen pimpinan; 6) adanya mutasi pengelola keuangan; dan 7) perubahan regulasi.

1. Kurangnya koordinasi dan komunikasi audit

Kebutuhan akan koordinasi tergantung pada sifat dan kebutuhan komunikasi dalam pelaksanaan tugas dan derajat saling ketergantungan. Koordinasi dan komunikasi adalah sesuatu hal yang tidak dapat dipisahkan. Menurut Gultom (2015), ada tiga aspek komunikasi yang perlu diperhatikan dalam pelaksanaan audit yaitu: komunikasi antara internal tim, komunikasi antara auditor dengan auditi serta komunikasi antara auditor dengan pihak lain yang terkait (instansi pemerintah, penyidik, pihak ketiga dan lain sebagainya).

Hubungan koordinasi dan komunikasi antara auditor Inspektorat dengan auditi serta dengan pihak lain yang terkait, tidak berjalan secara efektif. Komunikasi dalam penugasan audit antara auditor dengan auditi tidak berjalan dengan efektif terutama pada pelaksanaan audit, auditor kadang tidak menjalin komunikasi yang baik dengan auditi, komunikasi dilakukan nanti setelah pemeriksaan selesai dilaksanakan dengan meminta tanggapan dari auditi melalui Naskah Hasil Pemeriksaan. Hal tersebut tidak sesuai dengan pendapat Badjuri (2008) yang menyatakan bahwa komunikasi dalam audit sangat penting sebagai langkah awal auditor mengkomunikasikan tugas profesionalnya terhadap auditi. Komunikasi yang dibangun secara baik oleh auditor terhadap auditi akan mendorong kelancaran auditor dalam mencari dan mengalisis bukti-bukti audit yang dibutuhkan. Sementara pihak auditi bersikap pasif dalam melakukan koordinasi dengan auditor Inspektorat, koordinasi pada saat pemeriksaan bersifat kaku dan tidak ada tindak lanjut yang baik setelah pemeriksaan selesai dilaksanakan.

Disamping itu, berdasarkan hasil observasi, diketahui tidak terjalin kooordinasi dan kerjasama dalam kegiatan yang bersifat lintas sektoral antara SKPD perencanaan, pelaksana dan pengawasan. Hasil temuan pemeriksaan tidak ditindaklanjuti dengan koordinasi antara SKPD lintas sektoral terkait. Seharusnya hasil pemeriksaan dapat digunakan sebagai dasar acuan perencanaan kegiatan selanjutnya bagi SKPD terkait. 
2. Kurangnya kompetensi auditor dalam pengembangan temuan

Dalam Standar Umum 2000 Standar Audit Intern Pemerintah Indonesia (SAIPI) dijelaskan bahwa auditor harus mempunyai pendidikan, pengetahuan, keahlian dan keterampilan, pengalaman, serta kompetensi lain yang diperlukan untuk melaksanakan tanggungjawabnya. Auditor harus mengembangkan temuan yang diperoleh selama pelaksanaan audit karena pengembangan temuan sangat menentukan keberhasilan tugas audit.

Dalam pelaksanaan audit pada Inspektorat Kota Gorontalo, terdapat personil auditor yang kurang berkompeten dalam hal pengembangan temuan audit. Tahapan audit tidak dilakukan dengan tepat, penyebab temuan tidak memperbaiki sistem dari permasalahan yang terjadi serta rekomendasi tidak menghilangkan penyebab dan sulit untuk dilaksanakan. Hal ini dapat mengakibatkan auditi akan sulit menindaklanjuti temuan dan tidak dapat mengambil langkah-langkah perbaikan yang tepat sehingga memungkinkan untuk terjadinya temuan yang sama di masa yang akan datang.

Hal tersebut tidak sesuai dengan Standar Umum dalam Standar Audit Intern Pemerintah Indonesia (2013) seksi 2010 yang menyatakan bahwa auditor harus mempunyai pendidikan, pengetahuan, keahlian dan keterampilan, pengalaman, serta kompetensi lain yang diperlukan untuk melaksanakan tanggung jawabnya. Simamora (2002) juga mengatakan bahwa salah satu prinsip yang harus dimiliki seorang auditor dalam menjalankan profesinya adalah kompetensi dan kehati-hatian profesional. Setiap anggota harus melaksanakan jasa profesionalnya dengan hati-hati, kompetensi dan ketekunan, serta mempunyai kewajiban untuk mempertahankan pengetahuan dan keterampilan profesional.

\section{Kurangnya integritas dan nilai etika aparatur}

Jika nilai-nilai integritas dimiliki oleh aparatur didukung dengan sikap perilaku yang baik, tentunya sikap anti korupsi akan tertanam dalam dirinya dalam melakukan pekerjaan sehingga tidak akan terjadi kelalaian atau kesengajaan yang bertentangan dengan ketentuan yang berlaku. Berdasarkan hasil penelitiian, menunjukkan bahwa kurangnya integritas dan nilai etika aparatur dapat menyebabkan terjadinya risiko penyimpangan (temuan) yang berulang. Pada umumnya seorang aparatur yang telah melakukan penyimpangan, akan berperilaku tidak etis dan tidak memiliki rasa tanggung jawab terhadap pekerjaannya sehingga penyimpangan yang sama akan terjadi lagi di masa yang akan datang selama aparat tersebut tidak menyadari kesalahannya dan berkemauan untuk mengembangkan diri ke arah yang lebih baik. Oleh karena itu, penegakan integritas dan nilai etika dari seorang aparatur sangat dibutuhkan untuk mewujudkan pemerintahan yang bersih, bebas dari salah saji dan kecurangan. Hal ini sesuai dengan pernyataan Wiranta (2015) bahwa tanpa adanya standar etika dan integritas maka akan sangat sulit untuk mencegah penyalahgunaan wewenang, korupsi, dan sejenisnya.

\section{Lemahnya sistem pengendalian intern}

Sistem pengendalian intern menurut PP Nomor 60 Tahun 2008 adalah suatu proses yang integral pada tindakan dan kegiatan yang dilakukan secara terus menerus oleh pimpinan dan seluruh pegawai untuk memberikan keyakinan memadai atas tercapainya tujuan organisasi melalui kegiatan yang efektif dan efisien, keandalan pelaporan keuangan, pengamanan aset negara dan ketaatan terhadap peraturan perundangundangan. Oleh karena itu, setiap instansi pemerintah wajib menerapkan 
setiap unsur dari sistem pengendalian intern untuk dapat memberikan keyakinan yang memadai atas tercapainya tujuan organisasi serta untuk mengurangi kemungkinan terjadinya kesalahan dan tindakan yang tidak sesuai dengan peraturan perundangundangan. Artinya, jika pengendalian intern suatu organisasi lemah, maka besar kemungkinan terjadi kesalahan atau kecurangan.

Hasil penelitian menunjukkan bahwa lingkungan pengendalian yang kondusif untuk menerapkan SPI pada SKPD masih sulit untuk dicapai karena terdapat kelemahan dalam pendelegasian wewenang dan tanggung jawab, kurangnya hubungan kerja yang baik serta kurang tertibnya penyusunan dan penerapan kebijakan tentang pembinaan SDM. Setiap SKPD belum membuat Rencana Tindak Pengendalian (RTP) yang merupakan salah satu langkah awal dalam menerapkan sistem pengendalian intern.

Hal ini sejalan dengan teori yang disampaikan Mulyadi (2008) dalam Pakadang (2013) bahwa salah satu tujuan sistem pengendalian intern yang efektif yaitu membantu agar tidak ada penyimpangan dari kebijakan-kebijakan manajemen yang ada. Artinya, dengan adanya sistem pengendalian intern yang efektif dalam suatu organisasi dapat memperkecil tingkat penyimpangan yang terjadi akibat dari kebijakan-kebijakan yang ada. Sebaliknya, suatu unit kerja yang pengendalian internnya lemah, memiliki kemungkinan yang cukup besar untuk terjadinya suatu pelanggaran/ penyimpangan.

5. Kurangnya komitmen pimpinan

Kusuma (2014) dalam penelitiannya menyimpulkan bahwa salah satu faktor penyebab terjadinya temuan pemeriksaan yang berulang adalah tidak adanya komitmen pimpinan Kepala SKPD dalam melaksanakan SPIP. Dalam PP Nomor 60 Tahun 2008 tentang SPIP, dijelaskan bahwa pendelegasian wewenang harus diberikan kepada pegawai yang tepat sesuai dengan tingkat tanggungjawabnya dalam rangka pencapaian tujuan instansi pemerintah.

Hal tersebut berbeda dengan yang terjadi di lingkungan Pemerintah Kota Gorontalo, dimana masih terdapat beberapa pimpinan SKPD yang tidak memiliki komitmen dalam mencapai tujuan organisasi/instansi pemerintah dibuktikan dengan masih memberikan wewenang tanggungjawab kepada aparatur yang tidak tepat serta tidak memberikan punishment atau sanksi yang tegas kepada aparatur yang telah melakukan penyimpangan. Kewajiban pimpinan SKPD dalam menindaklanjuti rekomendasi hasil pemeriksaan Inspektorat juga tidak dilaksanakan secara maksimal.

Dengan demikian dapat disimpulkan bahwa penyelenggaraan pemerintahan yang bersih hanya dapat tercapai jika ada komitmen dari pimpinan SKPD dan pengelola keuangan yang berperilaku positif serta mampu mengantisipasi terjadinya kesalahan/ penyimpangan yang merugikan keuangan daerah sehingga tidak akan terjadi lagi kesalahan yang sama di kemudian hari. Artinya, salah satu hal yang menyebabkan terjadinya penyimpangan atau temuan yang berulang adalah tidak adanya komitmen pimpinan SKPD dalam mewujudkan tujuan organisasi.

Hasil penelitian ini terkait dengan teori komitmen organisasi yang dikemukakan Meyer dan Allen (1997). Kurangnya komitmen pimpinan tidak selaras dengan komitmen normatif (normative commitment) yaitu adanya komitmen yang tinggi dalam organisasi dengan perasaan memiliki kewajiban atas tugas dan tanggung jawab untuk bertingkah laku secara baik dan melakukan tindakan tepat bagi organisasi dalam rangka mewujudkan tujuan organisasi sehingga dapat mencegah dan meminimalisir terjadinya penyimpangan. 
6. Adanya mutasi pengelola keuangan Dalam PP 60 Tahun 2008 tentang SPIP, unsur lingkungan pengendalian dalam instansi pemerintah dapat dilakukan melalui adanya kepemimpinan yang kondusif diantaranya tidak ada mutasi pegawai yang berlebihan di fungsifungsi tertentu seperti pengelola kegiatan operasional dan program, akuntansi atau pemeriksa intern yang mungkin menunjukkan adanya masalah dengan perhatian pemerintah terhadap pengendalian intern. Artinya, pegawai yang menduduki posisi penting tidak bisa keluar atau mengundurkan diri dengan alasan yang tidak jelas sehingga tidak mengakibatkan tingkat perputaran pegawai yang tinggi yang dapat melemahkan pengendalian intern serta mengindikasikan kurangnya perhatian pimpinan instansi pemerintah terhadap pengendalian intern.

Berdasarkan hasil penelitian dapat disimpulkan bahwa tingginya mutasi pegawai yang memiliki jabatan penting dalam SKPD seperti Bendahara/pengelola keuangan, dapat meningkatkan risiko terjadinya temuan pemeriksaan yang berulang. Dalam artian, apabila Bendahara/pengelola keuangan yang telah memiliki pengetahuan memadai (didukung dengan pelaksanaan bimtekbimtek dan pelatihan di bidang keuangan), diganti dengan Bendahara/ pengelola keuangan yang belum memiliki pengetahuan yang cukup mengenai pengelolaan keuangan daerah, akan mengakibatkan terjadinya kesalahan/ penyimpangan.

Penelitian ini selaras dengan teori yang dikemukakan oleh Conner dan Prahaland (1996) dan Grnt dalam Griffith et al. (1999) dalam Pratiwi dan Musmini (2014) yang menyebutkan bahwa pengetahuan merupakan sumber daya yang penting bagi suatu organisasi. Pengetahuan tentang pengelolaan keuangan daerah merupakan hal dasar yang harus dimiliki oleh pegawai/aparatur bagian keuangan di setiap SKPD agar dapat menjalankan fungsinya dalam pertanggungjawaban keuangan daerah dengan maksimal. Hal ini juga didukung oleh teori akuntansi positif yang dikemukakan oleh Watts dan Zimmerman (1986) dalam Yuni (2012) yang menjelaskan sebuah proses yang menggunakan pemahaman, pengetahuan dan kebijakan akuntansi yang paling sesuai untuk menghadapi kondisi dan keadaan tertentu pada masa yang akan datang. Artinya, penggunaan sumber daya manusia dan sumber daya pendukung lainnya memegang peranan penting dalam menunjang keefektifan implementasi suatu kebijakan dalam pengelolaan keuangan yang dilaksanakan baik di masa sekarang maupun di masa yang akan datang. Dengan adanya kemampuan dan pengetahuan akuntansi yang memadai, diharapkan setiap aparat pengelola keuangan/Bendahara dapat terhindar dari adanya salah saji dalam pertanggungjawaban keuangan daerah.

\section{Adanya perubahan regulasi}

Dalam PP Nomor 60 Tahun 2008 pada unsur penilaian risiko, dijelaskan bahwa pimpinan instansi pemerintah sebagai evaluator harus berkonsentrasi pada penetapan tujuan instansi, pengidentifikasian dan analisis risiko serta pengelolaan risiko pada saat terjadi perubahan-perubahan dalam pemerintahan, ekonomi, industri, peraturan, operasional atau kondisi lain yang dapat mempengaruhi tercapainya maksud dan tujuan Instansi Pemerintah secara keseluruhan atau maksud dan tujuan suatu kegiatan. Terbitnya suatu peraturan perundang-undangan yang terbaru atau perubahan atas suatu peraturan diantaranya akan berdampak pada perbedaan pemahaman atau interpretasi dari masing-masing pihak termasuk auditi sebagai pengelola kegiatan dan auditor sebagai lembaga pengawas.

Setiap satuan kerja harus selalu mengetahui terbitnya peraturan yang terbaru dan mengupdate perubahan atas suatu peraturan, untuk dapat melaksanakan tugas dan 
tanggung jawabnya dengan sebaik-baiknya sesuai ketentuan yang berlaku. Jika pihak SKPD terutama pelaksana kegiatan atau pengelola keuangan tidak memahami dengan jelas maksud dari suatu peraturan, akan mengakibatkan risiko terjadinya kesalahan/penyimpangan. Demikian juga dari sisi auditor dalam melaksanakan kegiatan pengawasan harus selalu berpedoman pada peraturan perundang-undangan yang terbaru demi tercapainya tujuan yang diinginkan agar nantinya temuan hasil pemeriksaan dapat dianggap valid sesuai dengan ketentuan yang berlaku. Jadi, dapat disimpulkan bahwa adanya perubahan regulasi yang tidak dibarengi dengan pemahaman yang jelas dari pihak auditi maupun auditor, dapat menyebabkan risiko tingginya tingkat penyimpangan sehingga temuan/penyimpangan yang sama dapat terjadi lagi di tahun-tahun selanjutnya.

\section{Peran Pembinaan Inspektorat Dalam Meminimalisir Temuan Berulang}

Menurut PP Nomor 79 Tahun 2005 tentang Pedoman Pembinaan dan Pengawasan Penyelenggaraan Pemerintah Daerah, pembinaan atas penyelenggaraan pemerintahan daerah adalah upaya yang dilakukan untuk mewujudkan tercapainya tujuan penyelenggaraan otonomi daerah yang dilaksanakan oleh Pemerintah dan/atau Gubernur selaku wakil pemerintah di daerah. Paradigma Inspektorat saat ini adalah sebagai Quality Assurance atau penjamin mutu dan Consulting Partner atau sebagai konsultan dan Early Warning System. Paradigma menjadi berubah yang tadinya sebagai pemeriksa, saat ini lebih ditekankan melakukan pembinaan kepada seluruh Satuan Kerja Perangkat Daerah (SKPD) yang bernaung di dalam Pemerintah Kota Gorontalo. Hal tersebut sangat perlu dilakukan guna mewujudkan tata kelola pemerintahan yang baik dan bersih dari praktik-praktik Korupsi, Kolusi dan Nepotisme (KKN).

Inspektorat Kota Gorontalo dalam melaksanakan fungsinya sebagai lembaga pengawas, tidak hanya terbatas pada kegiatan pengawasan/audit tapi juga melaksanakan fungsi pembinaan terhadap satuan kerja pemerintah daerah (SKPD). Berdasarkan hasil penelitian dengan melakukan wawancara dan observasi didukung data dokumentasi, Inspektorat telah melakukan beberapa upaya dalam meminimalisir terjadinya temuan berulang pada SKPD di lingkungan Pemerintah Kota Gorontalo diantaranya dengan melaksanakan beberapa kegiatan dalam fungsi pembinaan seperti: 1) kegiatan Jumat Bersih Administrasi yang dilaksanakan setiap minggu; 2) kegiatan pelatihan (training) berupa pelatihan/bimbingan teknis, workshop, atau sosialisasi kepada SKPD; 3) pembinaanpembinaan non formal dengan mendatangani SKPD secara langsung, pembinaan yang bersifat insidentil, dan pembinaan pada saat pemeriksaan reguler; 4) membuat daftar risiko SKPD; 5) meningkatkan kompetensi dan profesionalisme auditor; dan 6) melaksanakan Sidang MP TP-TGR. Namun, pada kenyataannya upaya-upaya tersebut belum efektif karena masih ditemukan berbagai penyimpangan atau temuan pemeriksaan yang sama setiap tahunnya (temuan berulang).

\section{Penutup}

Kesimpulan penelitian adalah:

1. Faktor-faktor penyebab terjadinya temuan berulang atas pemeriksaan Inspektorat Kota Gorontalo antara lain; 1) kurangnya koordinasi dan komunikasi antara auditor Inspektorat dengan objek pemeriksaan (auditi) dan pihak-pihak lain yang terkait; 2) kurangnya kompetensi auditor dalam pengembangan temuan audit; 3 ) kurangnya integritas dan nilai etika aparatur; 4) lemahnya sistem pengendalian intern pada objek pemeriksaan (auditi); 
5) tidak adanya komitmen pimpinan SKPD dalam mewujudkan tujuan organisasi; 6) adanya mutasi pengelola keuangan; dan 7) adanya perubahan regulasi.

2. Peran Inspektorat dalam pembinaan pada SKPD di lingkungan Pemerintah Kota Gorontalo dalam upaya meminimalisir terjadinya temuan berulang dilakukan melalui beberapa kegiatan yaitu: 1) kegiatan Jumat Bersih Administrasi; 2) pelatihan (training); 3) pembinaan- pembinaan non formal; 4) membuat daftar risiko SKPD; 5) meningkatkan kompetensi dan profesionalisme auditor; dan 6) melaksanakan Sidang MP TP-TGR.

Saran yang dapat diberikan bagi auditor/pimpinan Inspektorat adalah: 1) memperbaiki komunikasi dan koordinasi dengan objek pemeriksaan dan SKPD terkait lainnya; 2) lebih meningkatkan kompetensinya terutama dalam hal pengembangan temuan audit; 3 ) melakukan pendampingan penerapan SPIP kepada seluruh satuan kerja; 4) lebih menekankan pemahaman dan komitmen Pimpinan SKPD dalam mencapai tujuan organisasi; dan 5) lebih meningkatkan kuantitas dan kualitas pembinaan kepada seluruh satuan kerja. Sedangkan untuk pimpinan SKPD (auditi) diantaranya; 1) lebih aktif dalam melakukan koordinasi lebih lanjut dengan Inspektorat; 2) melakukan pengendalian dalam bentuk penerapan SPIP; 3) membuat aturan perilaku; 4) membuat Standar Operasional Prosedur (SOP) untuk setiap kegiatan.

\section{Daftar Pustaka}

Amirin. 2009. Objek, Subjek, dan Populasi Penelitian.

Astriani, Devi. 2013. The Influence Resolution Of Audit Findings On The Quality Of Local Government Finance (Survey on Badan Pengawasan Keuangan dan Pembangunan (BPKP) Representative West Java Province). Fakultas Ekonomi Universitas Widyatama Bandung.

Badjuri, Achmad. 2008. Pendekatan Psikologi dan Komunikasi Audit Dalam Mendukung Penugasan Profesional Audit. Fakultas Ekonomi Universitas Stikubank Semarang. Vol. 7, No. 3, Hal. 164-172, ISSN: 1412-3851.

Cahill, Lawrence B. 2012. Repeat Versus Recurring Findings in EHS Audits. Pratical Solutions for Environmental, Health and Safety Professionals. EHS Journal, category: Auditing.

Gultom, Obbie Afri. 2015. Komunikasi Audit Intern: Komunikasi Selama Pelaksanaan Audit.

Isminarsih, Prasetyono dan Bambang Haryadi. 2015. Temuan Berulang dan Tindak Lanjut Hasil Pemeriksaan (Studi Pada Inspektorat Kabupaten X). Program Studi Magister Akuntansi. Universitas Trunojoyo Madura.

Kusuma, Widya Ardiyanti. 2014. Dinamika Hubungan Inspektorat Dengan Obyek Pemeriksaan Dalam Penanganan Temuan Pemeriksaan Yang Berulang Tahun 2010 2013 (Studi Kasus pada Inspektorat Kabupaten Bojonegoro). (Tesis). Fakultas IImu Sosial dan Ilmu Politik - Universitas Gadjah Mada.

Meyer, JP \& Allen, NJ. 1997. Commitment In The Workplace: Theory, Research and Application. Thousand Oaks. California: Sage Publication, Inc.

Pakadang, Desi. 2013. Evaluasi Penerapan Sistem Pengendalian Intern Penerimaan Kas pada Rumah Sakit Gunung Maria di Tomohon. Fakultas Ekonomi dan Bisnis Universitas Sam Ratulangi Manado. Jurnal EMBA Vol. 1, No. 4, Hal. 213-223. ISSN: 23031174.

Peraturan Pemerintah Nomor 60 Tahun 2008 tentang Sistem Pengendalian Intern Pemerintah.

Peraturan Menteri Pendayagunaan Aparatur Negara \& Reformasi Birokrasi Nomor 05 Tahun 2008 tentang Standar Audit Aparat Pengawasan Intern Pemerintah (SAAPIP).

Pratiwi, Putu Anisa Septi Asri dan Lucy Sri Musmini. 2014. Pengaruh Pengetahuan Pengelolaan Keuangan Daerah, Personal Background, dan Komitmen Terhadap 
Kemampuan Satuan Kerja Perangkat Daerah Dalam Penyusunan Laporan Keuangan Daerah (Studi Pada SKPD di Pemerintahan Daerah Kabupaten Klungkung). e-Journal Jurusan Akuntansi Universitas Pendidikan Ganesha. Volume 2 No. 1.

Rai, I Gusti Agung. 2008. Audit Kinerja pada Sektor Publik. Jakarta: Salemba Empat.

Simamora, Henry. 2002. Auditing. Yogyakarta: Unit Penerbit dan Percetakan (UPP) AMP YKPN.

Sugiyono. 2015. Memahami Penelitian Kualitatif. Bandung: Alfabeta.

Wiranta, Dayat NS. 2015. Transformasi Birokrasi: Cara Untuk Penguatan Etika dan Integritas dalam Pencegahan Korupsi. Pusat Kajian dan Pendidikan dan Pelatihan Aparatur, Lembaga Administrasi Negara JatinangorSumedang. Jurnal Lingkar Widyaiswara Edisi 2 No. 4, p. 44-71 ISSN: 2355-4118.

Yuni, Irma. 2012. Akuntansi Positif dan Akuntansi Normatif. 